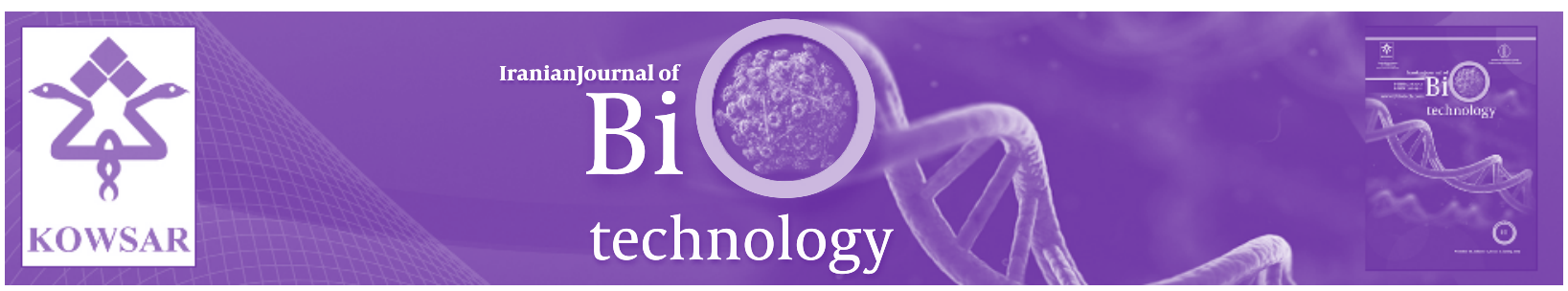

\title{
Development of a High-Resolution Melting Method for Screening R188H Pol- ymorphism in XRCC2 Gene
}

\author{
Shima Fayaz ${ }^{1}$, Pezhman Fard-Esfahani ${ }^{1, *}$, Shahnaz Khaghani ${ }^{2}$ \\ ${ }^{1}$ Department of Biochemistry, Pasteur Institute of Iran, Tehran, IR Iran \\ ${ }^{2}$ Department of Biochemistry, Faculty of Medicine, Tehran University of Medical Sciences, Tehran, IR Iran \\ ${ }^{*}$ Corresponding author: Pezhman Fard-Esfahani, Department of Biochemistry, Pasteur Institute of Iran, Tehran, IR Iran. Tel: +98-2166953311, Fax: +98- \\ 2166402770, E-mail: fard-esfahani@pasteur.ac.ir.
}

\section{A B S T R A C T}

Background: The High Resolution Melting (HRM) method is a new scanning method for detecting unknown changes in DNA and its advantages have persuaded researchers to recruit it as a screening method.

Objectives: Here, we developed a HRM method to screen R188H SNP (rs3218536) of XRCC2 and compared the results with a well known PCRRFLP technique.

Materials and Methods: Genomic DNA samples from 350 healthy individuals were obtained. PCR-HRM analysis and PCR-RFLP method were performed simultaneously.

Results: Three different melting profiles corresponding to three different genotypes recognized by HRM analysis. The results of PCR-RFLP showed no discrepancy.

Conclusions: We concluded that the HRM technique can be used as a screening method for rapid discrimination of R188H genotypes in XRCC2 gene.

Keywords: HRM; XRCC2; Genotyping

Copyright (c) 2013, National Institute of Genetic Engineering and Biotechnology; Published by Kowsar Corp.

Article type: Brief Report; Received: 07 Oct 2012; Revised: 15 Jan 2013; Accepted: 04 Mar 2013; Epub: 22 May 2013; Ppub: 2013, Ppub: June 2013

Implication for health policy/practice/research/medical education:

Early detection of cancer and cancer researchers.

Please cite this paper as:

Development of a High-Resolution Melting Method for Screening R188H Polymorphism in XRCC2 Gene. Iran J Biotech. 2013: 11(2): 104-8. DOI: $10.5812 / \mathrm{ijb} .11450$

Copyright @ 2013, National Institute of Genetic Engineering and Biotechnology; Published by Kowsar Corp.

This is an Open Access article distributed under the terms of the Creative Commons Attribution License (http://creativecommons.org/licenses/by/3.0), which permits unrestricted use, distribution, and reproduction in any medium, provided the original work is properly cited. 


\section{Background}

DNA repair genes are involved in the maintenance of genomes integration. Defects in DNA repair genes may contribute to the development of various types of cancers (1-4). X-ray repair cross-complementing group 2 (XRCC2), is one of the DNA repair genes which works in the homologous repair pathway (5). There are plenty of reported SNPs in this gene (http://www.ncbi.nlm.nih. gov/projects/SNP/snp_ref.cgi?geneId=7516) where $R 188 H$ (rs3218536) is the most studied (6). This non-synonymous polymorphism ( $G$ to $A$ ) causes a non-conservative change in the level of protein expression which may alter its DNA repair functional activity (7). Many studies have been conducted to show possible associations of this polymorphism with various cancers (8-10). Various techniques have been used for $\mathrm{R} 188 \mathrm{H}$ genotyping but most of them include mutation detection screening methods, such as PCR-RFLP and TaqMan allele discrimination techniques. However, these techniques have some potential disadvantages: PCR-RFLP technique is time consuming and in this case uses a relatively expensive restriction enzyme. Taqman probes are expensive and setting up the technique may require considerable effort. As a large number of samples should be tested in molecular-epidemiological studies, high throughput techniques are needed. To address this demand, we used a high resolution melting (HRM) method to discriminate $\mathrm{R} 188 \mathrm{H}$ genotypes. This rapid and relatively new mutation scanning method has some advantages over similar gel based scanning methods (i.e. DGGE, SSCP and CSGE). For example, compared to a modified and rapid CSGE technique $(11,12)$, HRM method is much faster. Also, HRM has been successfully used as a mutation detection screening technique in other genes (13).

\section{Objectives}

Assessment of HRM method to discriminate $\mathrm{R} 188 \mathrm{H}$ genotypes as a fast and high throughput screening method and compare it to PCR-RFLP method.

\section{Materials and Methods}

In this study 350 human genomic DNA samples were genotyped for $\mathrm{R} 188 \mathrm{H}$ polymorphism in XRCC2 gene using PCR-HRM method and the results were compared with PCR-RFLP results obtained from the same samples. Samples were collected from healthy volunteers from two academic centers. After signing the genetic test's consent form by all candidates, peripheral blood sam- ples were collected in EDTA tubes and genomic DNA of white blood cells were extracted using a previously described salting out method (14). R188H Genotyping: $\mathrm{R} 188 \mathrm{H}$ alleles of XRCC2 gene from each sample were screened using polymerase chain reaction followed by high resolution melting (PCR-HRM) analysis using Rotor- Gene ${ }^{\mathrm{TM}} 6000$ real time rotary analyzer (Corbett Research, Qiagen). Four previously known genotype samples were included in each run (two for each 188RR and 188RH genotypes). These control samples were used as unique analysts in every run to test reproducibility. Forward and reverse primers were designed. A $104 \mathrm{bp}$ fragment of exon 3 from XRCC2 gene containing codon 188 was amplified using GGA AAT GTT CTC AGT GCT TAG AG and TTC TTC TGA TGA GCT CGA GG primers. The PCR-HRM reactions were carried out in a $10 \mu \mathrm{l}$ volume using Type-it HRM PCR Kit (Qiagen) containing 10 pmol of each primer and 20-50 ng genomic DNA. The PCR cycling temperature was: $95^{\circ} \mathrm{C}$ for $5 \mathrm{~min} ; 45 \mathrm{X}\left(95^{\circ} \mathrm{C}\right.$ $10 \mathrm{~s}, 59^{\circ} \mathrm{C} 30 \mathrm{~s}, 72^{\circ} \mathrm{C} 10 \mathrm{~s}$ ); $72^{\circ} \mathrm{C}$ for $4 \mathrm{~min}$; followed by PreHRM heteroduplex enrichment: $95^{\circ} \mathrm{C}$ for $10 \mathrm{~s} ; 65^{\circ} \mathrm{C}$ for 5 min and HRM protocol was: Ramp, from $65^{\circ} \mathrm{C}$ to $95^{\circ} \mathrm{C}$; increasing by $0.05^{\circ} \mathrm{C}$ at each step and waiting for $10 \mathrm{~s}$ in each round. After PCR-HRM, the same samples were treated with SexA1 restriction enzyme (RE) (Fermentas) using the manufacturer's protocol and were subjected to $3.5 \%$ agarose gel electrophoresis and ethidium bromide visualization.

\section{Results}

After RE treatment, PCR products carrying the wild type allele (188R) remained intact, while presence of the $188 \mathrm{H}$ allele produced two fragments of $61 \mathrm{bp}$ and $53 \mathrm{bp}$. Simultaneously, based on melting profiles, three main groups were retrieved (see below) and four samples from each group were randomly selected and subjected to DNA sequencing. The third group consisted of two samples and both samples were sequenced. HRM runs for the 65 samples are shown in Figure 1 A, B. Three different melting profiles could be recognized (Figure $1 \mathrm{~B}$ ). The profile of each control sample fell in a separate group. DNA sequencing of a few samples, each from a control-containing group confirmed $\mathrm{R} 188 \mathrm{H}$ heterozyosity and $188 \mathrm{R}$ homozygosity in the same relevant group (Figure $2 \mathrm{~A}$ ). Also, DNA sequencing of the samples belonging to the third group showed $188 \mathrm{H}$ homozygosity. PCR-RFLP results are shown in Figure 2 B. No discrepancy was seen between the resultant alleles from PCR-HRM and PCR-RFLP techniques. 
Figure 1. HRM of a Segment of Exon 3 of XRCC2 Gene
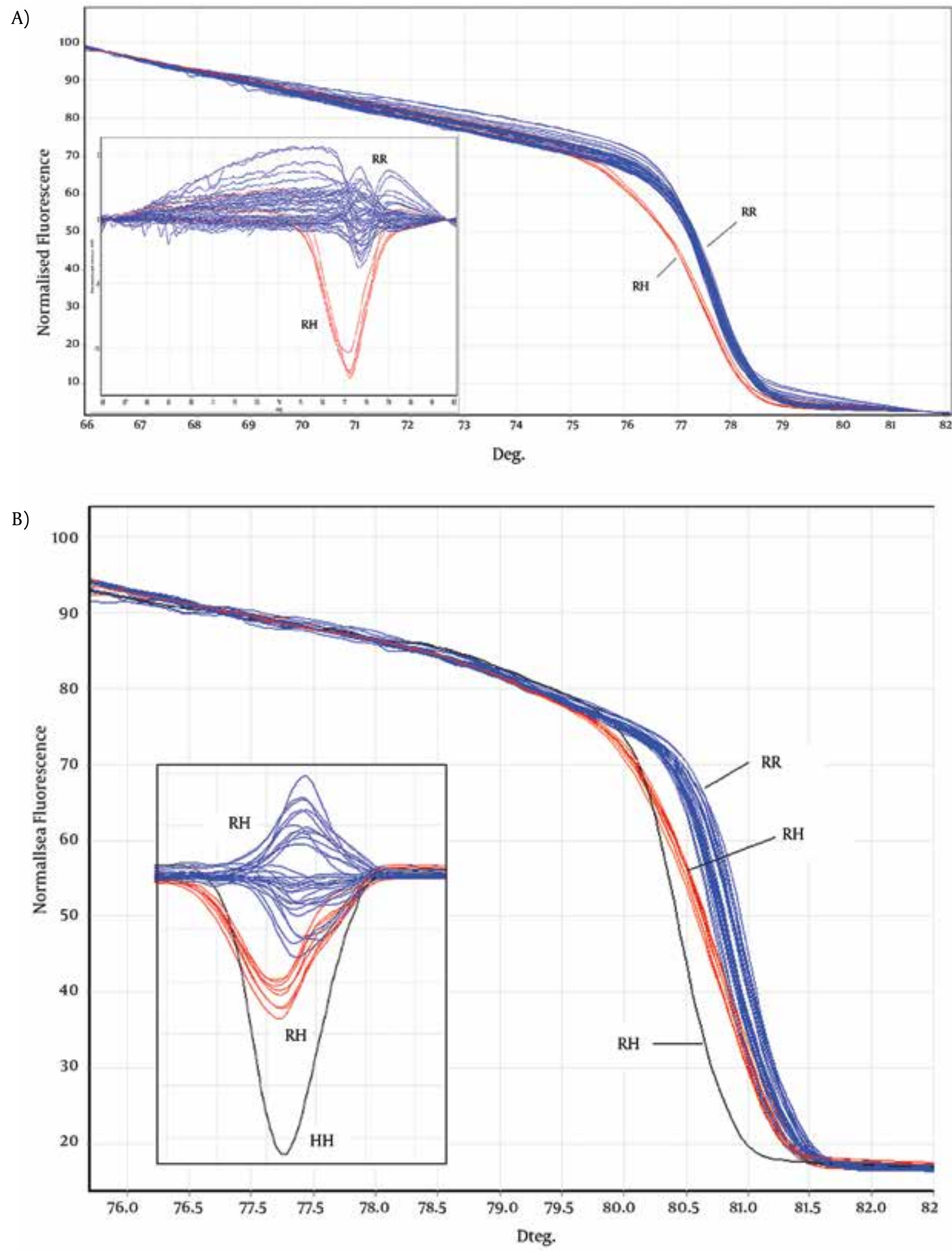

HRM of a segment of exon 3 of XRCC2 gene in 49 (A) and 16 (B) samples including 188RR and 188RH control samples. RR-type, RH-type and HH-type curves are shown as RR, RH and HH respectively. Small boxes show difference graphs. No HH-type was found in the 49 samples (A). 
A
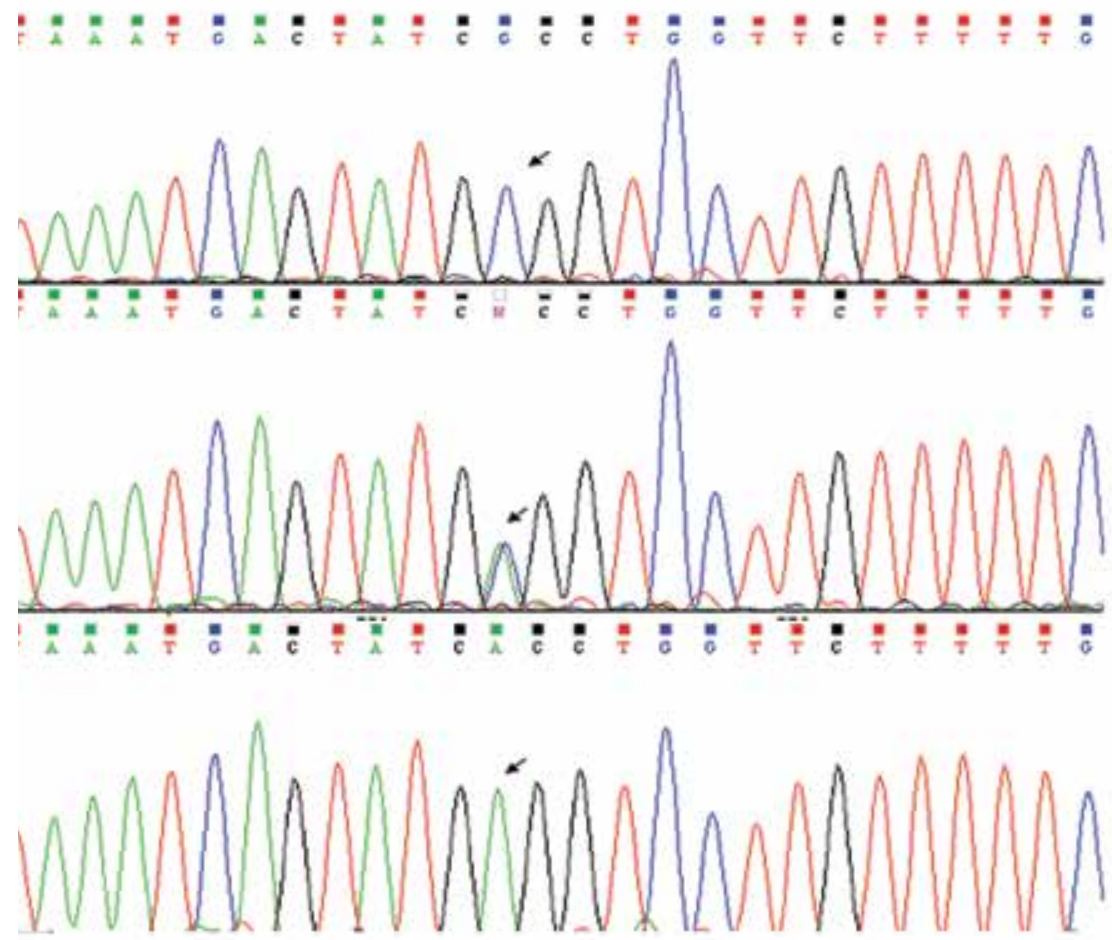

B

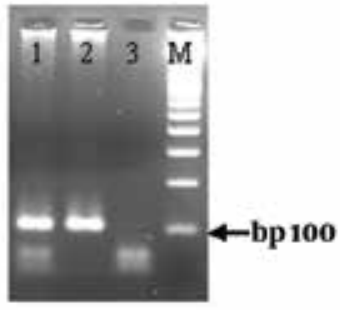

(A) Electropherograms of 188RR (up), 188RH (middle) and 188HH (down) genotypes. (B) RFLP samples: lane 1, 188RH; lane 2, 188RR; lane 3, 188HH and M, 100 bp DNA ladder.

\section{Discussion}

The importance of DNA repair genes in modifying the risk of developing cancer is not a subject that could be neglected. There are more than 20 DNA repair genes in different DNA repair pathways (15) in which plenty of single nucleotide polymorphisms are recognized. Therefore, using rapid SNP detection methods is crucial in genotyping studies. $\mathrm{R} 188 \mathrm{H}$ polymorphism in XRCC2 gene is one of the changes and its association with different cancers has been shown to lead to various outcomes. For example presence of the $188 \mathrm{RH}$ allele has been associated with decreased risk of breast cancer (16), but an increased risk of pancreatic cancer (9). In spite of the general view that HRM should be used as a scanning method for the detection of an unknown DNA polymorphism, we suggest that it can also be used as a screening method for the detection of specific polymorphisms, where no frequent SNPs have been reported in their proximity. Accordingly, we found that $R 188 H$ polymorphism in XRCC2 gene was a good candidate. Indeed, we designed primers to amplify a small PCR fragment to minimize the chance for the presence of other polymorphisms around $\mathrm{R} 188 \mathrm{H}$. In the present study we analyzed 350 genomic DNA for $\mathrm{R} 188 \mathrm{H}$ polymorphisms by PCR-HRM technique. To our knowledge, this was the first time that the HRM technique was implicated for genotyping of $\mathrm{R} 188 \mathrm{H}$ changes in XRCC2 gene. No discrepancy was found between these results and those obtained from the PCR-RFLP method. The simplicity, speed and accuracy of the PCR-HRM method convinced us that it could be used for screening $R 188 H$ polymorphism in XRCC2 gene. Moreover, the probable power of the PCR-HRM method for screening of other single nucleotide polymorphisms in other sites of the genome is a subject not far from imagination.

\section{Acknowledgements}

This project was supported by the Pasteur Institute of Iran and Tehran University of Medical Sciences. The authors do not have any conflicts of interest to report for this manuscript.

\section{Authors' Contribution}

Pezhman Fard-Esfahani designed and directed this study, Shima Fayaz did HRM and RFLP analysis and wrote the manuscript, Shahnaz Khaghani contributed to data analysis. 


\section{Financial Disclosure}

The authors stated that they had no interests which might be posing a conflict.

\section{Funding/Support}

This study was partly supported by Pasteur Institute of Iran and partly by Tehran University of Medical Sciences.

\section{References}

1. Arizono K, Osada Y, Kuroda Y. DNA repair gene hOGG1 codon 326 and XRCC1 codon 399 polymorphisms and bladder cancer risk in a Japanese population.Jpn J Clin Oncol. 2008;38(3):186-91.

2. Hu Z, Ma H, Chen F, Wei Q, Shen H. XRCC1 polymorphisms and cancer risk: a meta-analysis of 38 case-control studies. Cancer Epidemiol Biomarkers Prev. 2005;14(7):1810-8.

3. Wang Y, Yang H, Li H, Li L, Wang H, Liu C, et al. Association between X-ray repair cross complementing group 1 codon 399 and 194 polymorphisms and lung cancer risk: a meta-analysis. Cancer Lett. 2009;285(2):134-40.

4. Zhou C, Zhou Y, Li J, Zhang Y, Jiang L, Zeng X, et al. The Arg194Trp polymorphism in the X-ray repair cross-complementing group 1 gene as a potential risk factor of oral cancer: a meta-analysis Tohoku JExp Med. 2009;219(1):43-51.

5. Liu N, Lamerdin JE, Tebbs RS, Schild D, Tucker JD, Shen MR, et al. XRCC2 and XRCC3, new human Rad51-family members, promote chromosome stability and protect against DNA cross-links and other damages. Mol Cell. 1998;1(6):783-93.

6. Bastos HN, Antao MR, Silva SN, Azevedo AP, Manita I, Teixeira V, et al. Association of polymorphisms in genes of the homologous recombination DNA repair pathway and thyroid cancer risk. Thyroid. 2009;19(10):1067-75.

7. Danoy P, Sonoda E, Lathrop M, Takeda S, Matsuda F. A naturally occurring genetic variant of human XRCC2 (R188H) confers increased resistance to cisplatin-induced DNA damage. Biochem Biophys Res Commun. 2007;352(3):763-8.

8. Benhamou S, Tuimala J, Bouchardy C, Dayer P, Sarasin A Hirvonen A. DNA repair gene XRCC2 and XRCC3 polymorphisms and susceptibility to cancers of the upper aerodigestive tract. Int J Cancer. 2004;112(5):901-4.

9. Jiao L, Hassan MM, Bondy ML, Wolff RA, Evans DB, Abbruzzese JL, et al. XRCC2 and XRCC3 gene polymorphism and risk of pancreatic cancer. Am J Gastroenterol. 2008;103(2):360-7.

10. Rafii S, O'Regan P, Xinarianos G, Azmy I, Stephenson T, Reed $\mathrm{M}$, et al. A potential role for the XRCC2 R188H polymorphic site in DNA-damage repair and breast cancer. Hum Mol Genet. 2002;11(12):1433-8.

11. Fard-Esfahani P, Khatami S, Zeinali C, Taghikhani M, Allahyari M A modified conformation sensitive gel electrophoresis (CSGE) method for rapid and accurate detection of low density lipoprotein (LDL) receptor gene mutations in Familial Hypercholesterolemia. Clin Biochem. 2005;38(6):579-83.

12. Suh Y, Vijg J. SNP discovery in associating genetic variation with human disease phenotypes. Mutat Res. 2005;573(1-2):41-53.

13. Whittall RA, Scartezini M, Li K, Hubbart C, Reiner Z, Abraha A, et al. Development of a high-resolution melting method for mutation detection in familial hypercholesterolaemia patients. Ann Clin Biochem. 2010;47(Pt1):44-55.

14. Miller SA, Dykes DD, Polesky HF. A simple salting out procedure for extracting DNA from human nucleated cells. Nucleic Acids Res. 1988;16(3):1215.

15. Chistiakov DA, Voronova NV, Chistiakov PA. Genetic variations in DNA repair genes, radiosensitivity to cancer and susceptibility to acute tissue reactions in radiotherapy-treated cancer patients. Acta Oncol. 2008;47(5):809-24.

16. Pooley KA, Baynes C, Driver KE, Tyrer J, Azzato EM, Pharoah PD, et al. Common single-nucleotide polymorphisms in DNA doublestrand break repair genes and breast cancer risk. Cancer Epidemiol Biomarkers Prev. 2008;17(12):3482-9. 